\title{
Effect of Time, Cultivar and Rootstock on Success of Rose Propagation through Stenting Technique
}

\author{
Zeinab Izadi*, Hossein Zarei, Mahdi Alizadeh \\ Department of Horticultural Sciences, Gorgan University of Agricultural Sciences and Natural Resources, \\ Gorgan, Iran \\ Email: z.izadi89@gmail.com
}

Received 27 March 2014; revised 26 April 2014; accepted 7 May 2014

Copyright (C) 2014 by authors and Scientific Research Publishing Inc.

This work is licensed under the Creative Commons Attribution International License (CC BY). http://creativecommons.org/licenses/by/4.0/

c) (i) Open Access

\section{Abstract}

An experiment was undertaken to study the effects of two grafting times (1st of June and end of September) as well as kind of rootstock on growth and rooting of rose stentlings. Two Rosa species i.e. $R$. canina and $R$. manetti were selected as rootstock and three different hybrid tea rose cultivars namely Avalanch, Peach Avalanch and Dolcevita were grafted on them as scion through omega and splice techniques. The growth parameters were collected 57 days after grafting. The highest average of rooting, healing percentage, numbers of root, shoot and leaves were seen in September grafted plants. In overall Rosa canina was the best rootstock for Avalanch cultivar. Other observations did not lead to any prominent result as it varied with time of grafting, scion and rootstock cultivars.

\section{Keywords}

\section{Rootstock, Rose, Scion, Stenting, Grafting Time}

\section{Introduction}

The stenting (simultaneous cutting-grafting), as an efficient technique of propagation, has many advantages and is now being used worldwide by rose growers. Utilization of rootstocks in propagation of rose plants is a common practice. Although rose grafting has been exploited for a long time, few studies have been reported considering scion-rootstock relationship [1]. Earlier and recent comparative studies on rose rootstock performance have shown variable results due to various factors including a multitude of scion-rootstock combinations, rootstock

\footnotetext{
*Corresponding author.
}

How to cite this paper: Izadi, Z., Zarei, H. and Alizadeh, M. (2014) Effect of Time, Cultivar and Rootstock on Success of Rose Propagation through Stenting Technique. American Journal of Plant Sciences, 5, 1644-1650. 
clonal effects, type and depth of growing media, length of experimental period, geographic region, environmental parameters and cultural practices [2]. Varies and Dubois [3] observed that in grafted plants, vigor of the genotype used as a rootstock is transferred to the scion and thus influences growth and productivity. Younis and Riaze [4] investigated the effect of different rootstocks on rose propagation of two roses. Rosa bourboniana and "Grussanteplitz" were selected as rootstocks and three hybrid tea rose cultivars including Kardinal, "Gold medal" and "Whisky mac" were budded on them to study their compatibility, growth and development. Cultivars of Gold medal, Whisky mac and Kardinal showed maximum growth and flowering when budded on Grussanteplitz as compared to Rosa bourboniana. Investigation of rose propagation through stenting method showed that in the first year after stenting, $R$. chinensis "Indica Major" was found to be better rootstock for the cultivar "Cocktail 80" than R. canina "Inermis", while "Inermis" was better for "Motrea" [5]. Younis and Riaze [4] in their previous experiment found that among the mentioned varieties, Gold medal performed better than Whisky mac and Kardinal. The physiological stage of the mother plant, seasonal timing and the period of the year which cuttings are taken, can play important role in rooting. For many species, there is an optimal period of the year for rooting of the cuttings [6]. Seasonal variation influences endogenous hormone level and carbohydrate content [7]. Investigation of seasonal variation in rooting of the cuttings from Robinia pseudoacacia showed a positive relationship of rooting percentage between total carbohydrate concentration and $\mathrm{C} / \mathrm{N}$ ratio [8]. The RNA level of shoot is considered to be an index of bud activity, seasonal variation and rooting. In the highest rooting period of cutting, highest RNA level was observed in the shoot and highest activity in cambium layer. Often, the effect of season on rooting is correlated to cutting reaction to environmental condition during the year [9]. Investigation of seasonal variation in rooting of olive cuttings (prepared from 10 years old olive tree) showed that the highest rooting percentage of semi-hardwood cuttings of Leccino cultivar was obtained in spring season. Moderate temperature in the cambium region divides activity and physiological condition of cambium suitable for root initiation and development. It was reported that the best rooting percentage appeared during spring when cambium activity was highest and poor rooting or no rooting was seen during fall and winter periods when cambium activity was stopped [10]. There are several other reports considering the influence of season on "grafting take". The graft healing of walnut is highly influenced by environment, it means the graft take varied from $29 \%$ - $64 \%$ depending on the years. So, relations between the grafting take and climate conditions were also considered. Graft take under nursery conditions was affected by especially relative humidity (\%) in addition to the mean and maximum temperature $\left({ }^{\circ} \mathrm{C}\right)$ in August and September [11]. The present experiment was carried out to study the stenting propagation aspects of Rosa as influenced by time of stem cutting preparation and kind of scion and rootstocks. The study attempted to find out an acceptable and compatible rootstock for hybrid tea roses and best period of the year for propagation of rose via stenting technique.

\section{Materials and Methods}

\subsection{Plants Materials and Propagation Conditions}

Experiments were carried out in a fiberglass covered and, W-E oriented experimental greenhouse located in the north of Iran, Golestan province, Gorgan. The greenhouse equipped with intermitted mist and water coolers temperature and humidity modification. Two selected time periods i.e. 1st of June and end of September and two rose genotypes ( $R$. canina and $R$. manetti) were used as rootstock. Furthermore, Three kinds of greenhouse rose cultivars were used as scion including: Avalanch, Peach Avalanch, and Dolcevita.

\subsection{First Experiment}

First of all, some new shoots with proper thickness were selected and labeled. After two weeks, when labeled shoots were changed to semi-hardwood (faded flower stage), they were collected as scion woods. Both Scion and rootstocks shoots were obtained on the same day as bench-grafting was performed. The scions with 1 node and 1 leaf (including 2 leaflets) provided from the 2/3 of the base of each shoot. Similarly; semi-hard wood cuttings with at least two nodes (4 mm diameter) were provided from rootstock mother plants. In order to operate the omega and splice grafting techniques, Omega instrument and clipper were used respectively. Scions and rootstocks with acceptable smooth cut could be grafted together with the maximum overlap of the cambium layers. The graft portion was tightly covered with polyethylene tape. The basal $1 \mathrm{~cm}$ of each cutting was dipped for $5 \mathrm{sec}$ in IBA (at $5000 \mathrm{ppm}$ concentration) treatments. Immediately after grafting, all cut surfaces on the top of the scion thoroughly covered with grafting wax. Samples were then placed in a cocopeat-perlite (in 1:2 ratio) 
medium. The whole experiment was arranged as a factorial in the frame work of completely randomized design. Intermitted mist system was operated 2 minutes every 45 minutes from 7:00 am to 8:00 pm daily. Furthermore the mist system was programmed to be activated twice around midnight from 11:00 pm to 1:00 am as well. The mean temperature, light level and relative humidity of mid-day during the study period were $31^{\circ} \mathrm{C}, 12,000$ to 13,000 Lux and 70\% respectively. Grafting tapes were removed after 57 days and then root number, root length, leaf and shoot number, rooting and healing percentage of the grafted Plantlets were evaluated.

\subsection{Second Experiment}

This experiment was performed in late September. All the stages were similar to first experiment, but the mean temperature, light level and humidity during the study period were $27^{\circ} \mathrm{C}, 6000$ to $9000 \mathrm{Lux}$ and $70 \%$ respectively. The data were analyzed using SAS software.

\section{Results and Discussion}

Analysis of variance indicated that the effect of propagation time and cultivars on healing percentage and their interactions were statistically significant. Several researches have reported that grafting take influenced by environment condition. The temperature fluctuations and relative moisture especially during and after grafting directly affects the development of a good graft union. Temperature effects callus formation [9]. In the present study, highest grafting take percentage was found in the end of September (Table 1). The Average greenhouse temperature (during mid-day) in June was $31^{\circ} \mathrm{C}$ but in late of September, it was about $27^{\circ} \mathrm{C}$. The Rosa genus is endemic to temperature regions of the northern hemisphere [12]. Therefore its best growth takes place in cool climate. The results presented above strongly support this view. Moreover it seems temperature differences between two stages of experiment have influenced success of grafting. On the other hand, light level causes significant effect on the callus formation of cuttings definitely [13]. Higher grafting take in September may depend not only on the lower temperature but also lower light level. So, lower temperature in 2nd stage caused significant effect on the callus formation in the graft portion and increased grafting take percentage. It was hypothesized that early and delayed incompatibility may be involved with different genes. Compatibility is dependent on the presence of a particular factor or absence of the factors in both rootstock and scion.

The possibility of vary simple genetic control mechanism or of a threshold effect were raised. However, significant differences among clones within the compatibility status groups suggested that other factors probably are involved [14]. The relationship among measured factors in the present study indicated that interaction of scion and rootstock was significant; incompatibility signs did not seen even one year after grafting but Dolcevita on $R$. manetti had highest healing percentage (78.49\%) and Avalanch on $R$. manetti had lowest healing percentage (46.13\%), (Table 2). Result of interaction between time of propagation and type of cultivar showed $\mathrm{T}_{2} \mathrm{R}_{2} \mathrm{~S}_{3}$ had more healing percentage (Figure 1). According to the result of analysis of data (Table 1), the highest number of root was obtained in late of September.

Successful cutting propagation has been associated with the ideal time of stem cutting collection. Effect of season on the successful cutting can be correlated to change of $\mathrm{C} / \mathrm{N}$ level and endogenous auxin level in the mother plant tissues. It has been reported that $\mathrm{C} / \mathrm{N}$ ratio may be an important factor influencing the root ability of Thunbergia grandiflora cutting since the value of $\mathrm{C} / \mathrm{N}$ ratio were positively related to the rooting percentage

Table 1. The effect of grafting time on growth parameters and graft healing of rose stentlings.

\begin{tabular}{ccc}
\hline & & Grafting time \\
\hline Parameter & Beginning of June & Late September \\
\hline Number of roots & $2.89^{\mathrm{b}}$ & $3.12^{\mathrm{a}}$ \\
\hline Longest root size (cm) & $2.82^{\mathrm{a}}$ & $2.16^{\mathrm{b}}$ \\
Number of shoots & $1.33^{\mathrm{b}}$ & $1.63^{\mathrm{a}}$ \\
Number of leaves & $2.11^{\mathrm{b}}$ & $2.34^{\mathrm{a}}$ \\
\hline Healing percentage (\%) & $51.68^{\mathrm{b}}$ & $62.44^{\mathrm{a}}$ \\
\hline
\end{tabular}

Means in each row followed by different letters are statistically different using Duncan test $(p<0.05)$. 
Table 2. The effect of cultivar and rootstock on growth parameters and graft healing of rose stentlings.

\begin{tabular}{cccccccc}
\hline & \multicolumn{5}{c}{ Kind of scion and rootstock } \\
\hline Parameters & $\mathrm{S}_{1} \mathrm{R}_{1}^{* *}$ & $\mathrm{~S}_{2} \mathrm{R}_{1}$ & $\mathrm{~S}_{3} \mathrm{R}_{1}$ & $\mathrm{~S}_{1} \mathrm{R}_{2}$ & $\mathrm{~S}_{2} \mathrm{R}_{2}$ & $\mathrm{~S}_{3} \mathrm{R}_{2}$ \\
\hline Number of roots & $3.12^{\mathrm{b}}$ & $2.84^{\mathrm{d}}$ & $3.07^{\mathrm{bc}}$ & $2.87^{\mathrm{d}}$ & $3.34^{\mathrm{a}}$ & $2.81^{\mathrm{d}}$ \\
Longest root size (cm) & $2.83^{\mathrm{a}}$ & $2.55^{\mathrm{b}}$ & $2.52^{\mathrm{b}}$ & $2.53^{\mathrm{b}}$ & $2.38^{\mathrm{b}}$ & $2.06^{\mathrm{c}}$ & $78.49^{\mathrm{a}}$ \\
\hline Healing percentage (\%) & $53.05^{\mathrm{c}}$ & $51.38^{\mathrm{c}}$ & $63.71^{\mathrm{b}}$ & $46.13^{\mathrm{d}}$ & $54.70^{\mathrm{c}}$ & 78 . \\
\hline
\end{tabular}

Means in each row followed by different letters are statistically different using Duncan test $(p<0.05) .{ }^{* *} \mathrm{~S}=\mathrm{Scion}\left(\mathrm{S}_{1}\right.$ : Avalanch, $\mathrm{S}_{2}$ : Peach Avalanch, $\mathrm{S}_{3}$ : Dolcevita); $\mathrm{R}=$ Rootstock $\left(\mathrm{R}_{1}\right.$ : Rosa canina, $\mathrm{R}_{2}$ : Rosa manetti).

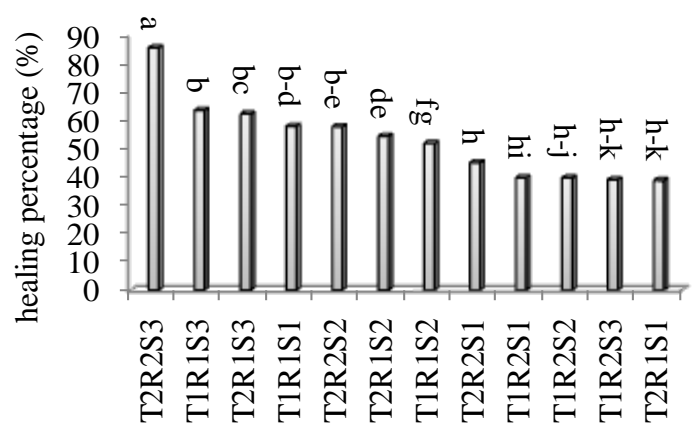

Interaction between treatments

Figure 1 . Interaction between time of propagation
and type of cultivar and rootstock on the healing per-
centage. $\mathrm{T}=$ Time of grafting $\left(\mathrm{T}_{1}: 1 \mathrm{st}\right.$ of June, $\mathrm{T}_{2}$ : end
of September); $\mathrm{S}=$ Scion $\left(\mathrm{S}_{1}:\right.$ Avalanch, $\mathrm{S}_{2}$ : Peach
Avalanch, $\mathrm{S}_{3}$ : Dolcevita); $\mathrm{R}=$ Rootstock $\left(\mathrm{R}_{1}\right.$ : Rosa
canina, $\mathrm{R}_{2}$ : Rosa manetti).

around the year [8]. The results obtained in the present research, showed that stentlings had highest root number in the 2nd stage (Table 1). Higher grafting take percent resulted in 2nd stage and whereas scion maintained its leaves, the carbohydrate and auxin supply from the leaves may have supported the root growth [7]. The excellent grafting take helpsauxin and carbohydrate transport to base of the cuttings and influenced their rooting. Jiao et al. [15] reported that carbohydrate export rate of expanded leaves on the flowering shoot was reduced by $80 \%$ under high temperature $\left(40^{\circ} \mathrm{C}\right)$ and suggested that temperature influences export and partitioning of assimilates. The export rate of carbohydrate depends on the maturation of leaf and shoot. In the beginning of June temperature was higher than late of September, so lower temperature in second experiment helped transporting of carbohydrate to the base of cuttings. Therefore lower temperature caused higher root number in this time (Table 1). On the other hand many researchers reported that there was a positive correlation between the endogenous IAA concentration and rooting ability of cuttings [8]. In the present study base of cuttings were treated with IBA (5000 ppm), hence in September endogenous auxin level probably was in appropriate rate therefore its interaction with exogenous auxin, provided good effect on formation of roots. Researchers stated that the growth of the rootstock is affected by the type of scion as well. Thus, when rough lemon seedlings were budded with "Malta" and "Santra" scions, a more fibrous root system is produced as compared to no-budded plants; and budding with "Malta" scions resulted to more root production than "Santra" scions. Effect of scion variety on the size, nature and form of root system has been reported in apple as well [16]. Under current research condition, Peach Avalanch on $R$. manetti, produced more root numbers. Peach Avalanch on $R$. canina, Avalanch on $R$. manetti and Dolcevita on $R$. manetti produced less number of roots (Table 2). Leaf removal during the first 7 days of propagation was the most critical issue for survival and growth of the stentlings. Stentlings with no leaf were developing stem black rot in few days. The original leaf area of cuttings has been a good indicator for growth and development of roots from cuttings and sort of insurance for establishment of the successful plants after transplantation. Leaf area is also a good indicator of growth potential of cuttings and planting material in case of severe reductions [17]. Another part of the results indicated that interaction between time of propagation and cultivars on mean number of root was significant and $T_{2} R_{1} S_{1}$ treatment was found to have more root numbers (Figure 2). 
The effect of time of propagation on scion and rootstock cultivars and interaction between time and cultivars was significant in the present study. Stentlings which were prepared and planted in 1st of June produced the longest root size $(2.82 \mathrm{~cm})$. Inverse relationship was also observed between root length and its number. Whereas, in late of September highest root number and lowest root length was observed (Table 1). Probably more nutritional materials and other factors which influencing rooting were used for more root numbers, therefore as result; root length have been reduced. Moreover interaction between endogenous hormone and exogenous IBA concentration was the cause of increase in root number, but it had a harmful effect on the length of roots. Hartman et al. [9] announced that high level of auxin may have negative effect on the root length. The longest root size was observed in Avalanch on $R$. canina. Dolcevita cultivar on $R$. manetti had less root size (Table 2). There are reports that scion vigor affected the weight of the rootstock $R$. canina "Inermis", and concluded that some roses are showing sciondominance [2]. The longest root size in current research was obtained in $T_{1} R_{1} S_{1}, T_{1} R_{1} S_{3}$ and $T_{1} R_{2} S_{1}$ but there were no significant differences between them (Figure 3).

The numbers of shoots were also significantly affected by time of propagation. The highest and lowest numbers of shoots were found in September and June treatments respectively (Table 1). New evidence confirms earlier postulates that root signals to shoots, including abscisic acid, nitrate flux, and cytokinins, modify whole plant growth processes including leaf expansion, stomatal behavior and biosynthesis of photosynthetic enzymes [1]. Roots are a major source of cytokinin (CK) production in the plant, and CK synthesized in the root is transported to

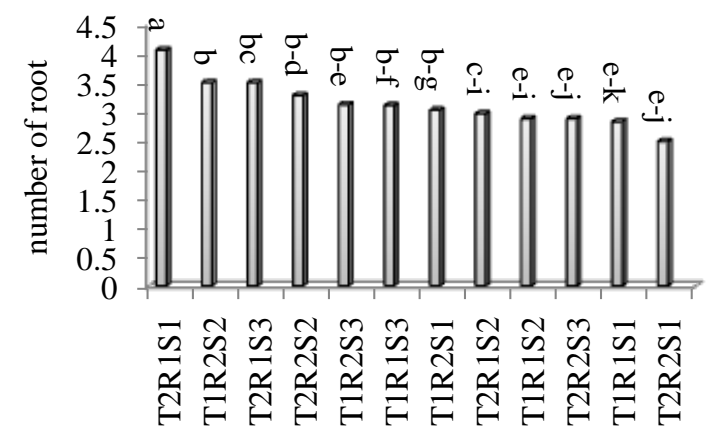

Interaction between treatments

Figure 2. Interaction between time of propagation, rootstocks and type of cultivar on the number of roots. $\mathrm{T}=$ Time of grafting $\left(\mathrm{T}_{1}\right.$ : 1st of June, $\mathrm{T}_{2}$ : end of September); $\mathrm{S}=$ Scion $\left(\mathrm{S}_{1}\right.$ : Avalanch, $\mathrm{S}_{2}$ : Peach Avalanch, $\mathrm{S}_{3}$ : Dolcevita); $\mathrm{R}=$ Rootstock $\left(\mathrm{R}_{1}\right.$ : Rosa canina, $\mathrm{R}_{2}$ : Rosa manetti).

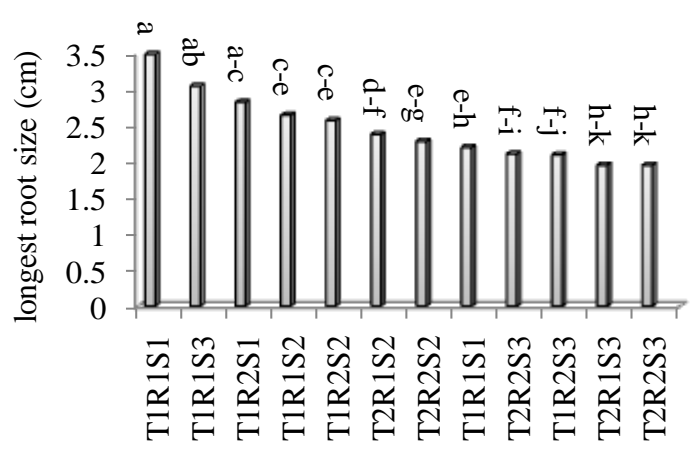

Interaction between treatments

Figure 3. Interaction between time of propagation, rootstock and type of cultivar on the longest root size. $\mathrm{T}=$ Time of grafting $\left(\mathrm{T}_{1}:\right.$ 1st of June, $\mathrm{T}_{2}$ : end of September); $\mathrm{S}=\mathrm{Scion}\left(\mathrm{S}_{1}\right.$ : Avalanch, $\mathrm{S}_{2}$ : Peach Avalanch, $\mathrm{S}_{3}$ : Dolcevita); $\mathrm{R}=$ Rootstock $\left(\mathrm{R}_{1}\right.$ : Rosa canina, $\mathrm{R}_{2}$ : Rosa manetti). 
the shoot in the transpiration stream of the xylem. The morphogenesis phenomenon is a main function of the cytokinins [18]. The highest shoot numbers were correlated to the highest root number in the September. As one of the well-known functions of the root is related to cytokinin synthesis then more numbers of roots could be related to more cytokinin supply. Cytokinin can be transported easily through vascular tissue and callus bridge in graft portion, so it promotes shoot initiation. Current result indicated that the effect of cultivars and interaction between times and cultivars were not significant (data not shown). The comparison between times of propagation indicated that, number of leaves was affected by time. All stentlings propagated in end of September had the highest numbers of leaves than first June (Table 1). Definitely more leaves were correlated with more numbers of shoots that was grown in the 2nd stage of propagation. Leaf number of stentling was not affected by type of cultivars and interaction between time and type of cultivars in current research (data not shown).

\section{Conclusion}

In conclusion, current study supports the claim that the productivity and quality of stentlings of greenhouse roses are influenced by the balance between the aerial parts and roots. The above obtained results have emphasized the improvement of propagation by stenting in late September for obtaining successful grafted plants. It was clearly demonstrated that Rosa canina was the best rootstock for Avalanch cultivar. Other observations did not lead to prominent result as it varied with time of grafting, scion and rootstock cultivars.

\section{References}

[1] Nazari, F., Khosh-Khui, M. and Salehi, H. (2009) Growth and Flower Quality of Four Rosa hybrid L. Cultivars in Response to Propagation by Stenting or Cutting in Soilless Culture. Scientia Horticulturae, 119, 302-305. http://dx.doi.org/10.1016/j.scienta.2008.08.004

[2] Cabreva, R.I. (2002) Rose Yield, Dry Matter Partitioning and Nutrient Status Responses to Rootstock Selection. Scientia Horticulturae, 95, 75-83. http://dx.doi.org/10.1016/S0304-4238(02)00020-1

[3] Varies, D.P. and Dubois, L.A.M. (1990) Shoot Production of “Sonia” on Hybrid Tea Rootstock Clones of Different Vigour. Gartenabuwissenschaft, 55, 268-271.

[4] Younis, A. and Riaz, A. (2005) Effect of Various Hormones and Different Rootstocks on Rose Propagation. Caderno de Pesquisa série Biologia, 17, 111-118.

[5] Van de Pol, P.A. and Breukelaar, A. (1982) Stenting of Rose: A Method for Quick Propagationby Simultaneously Cutting and Grafting. Scientia Horticulturae, 17, 187-196. http://dx.doi.org/10.1016/0304-4238(82)90012-7

[6] Bhusal, R.C., Mizutain, F., Moon, D.G. and Rutto, K.L. (2001) Propagation of Citrus by Stem Cuttings and Seasonal Variation in Rooting Capacity. Pakistan Journal of Biological Science, 4, 1294-1298. http://dx.doi.org/10.3923/pjbs.2001.1294.1298

[7] Stenvall, N., Haapala, T. and Pulkkinen, P. (2006) The Role of a Root Cutting's Diameter and Location on the Regeneration Ability of Hybrid Aspen. Forest Ecology and Management, 237, 150-155. http://dx.doi.org/10.1016/j.foreco.2006.09.040

[8] Ling, W.X. and Zhong, Z. (2010) Seasonal Variation in Rooting of the Cuttings from Tetraploid Locust in Relation to Nutrients and Endogenous Plant Hormones of the Shoot. Turkish Journal of Agriculture \& Forestry, 36, 257-266.

[9] Hartman, H.T., Kesrter, D.E. and Davis, F.T. (2002) Plant Propagation: Principles and Practices. Prentice Hall, Upper Saddle River.

[10] Ahmed, M., Laghari, M. H., Ahmed, I. and Khokhar, K.M. (2002) Seasonal Variation in Rooting of Leafy Olive Cuttings. Asian Journal of Plant Sciences, 1, 228-229. http://dx.doi.org/10.3923/ajps.2002.228.229

[11] Karadenize, T. (2005) Relation between Graft Success and Climatic Values in Walnut (Juglansregia). Central European Agriculture, 6, 631-634.

[12] Bhattacharjee, S.K. and Banerji, B.K. (2010) The Complete Book of Roses. Aavishkar Publishers, Jaipur.

[13] TavakkolAfshari, R., Angoshtari, R. and Kalantari, S. (2011) Effect of Light and Different Plant Growth Regulators on Inductions of Callus Growth in Repeseed (Brassica napus) Genotype. Journal of Plant Molecular Biology \& Omics, 4, 60-67.

[14] Dieters, M.J. and Haines, R.J. (1990) Influence of Rootstock Family and Scion Genotype on Graft Incompatibility in Araucaria cunninghammii Ait. ex D. Don. Silvae Genetica, 40, 141-146.

[15] Jiao, J., Gilmour, M., Tsujita, M.J. and Grodzinski, B. (1988) Photosynthesis and Carbon Partitioning in Samantha roses. Canadian Journal of Plant Science, 69, 577-584. http://dx.doi.org/10.4141/cjps89-071 
[16] Sadhu, M.K. (2005) Plant Propagation. New Age International Publisher, New Delhi.

[17] Costa, J.M. and Chall, H. (2002) The Effect of the Original Leaf Area on Growth of Softwood Cuttings and Planting Material of Rose. Scientia Horticulturae, 95, 111-121. http://dx.doi.org/10.1016/S0304-4238(02)00023-7

[18] Muller, D. and Leyser, O. (2011) Auxin, Cytokinin and the Control of Shoot Branching. Annals of Botany, 107, 12031212. http://dx.doi.org/10.1093/aob/mcr069 